8. Экспериментальное исследование коллагеновой матрицы для увеличения объема десны с использованием 3d-моделирования / Баулина И.М., Бадалян В.А., РяховскийА.Н. // Стоматология. 2015. Т. 94, №5. - С.8-10.

9. Применение десневого матрикса в комплексном лечении одонтогенногоперфоративного верхнечелюстного синусита. Лазутиков Д.О., Лазутиков О.В., Морозов А.Н.Чиркова Н.В.Научномедицинский вестник центрального черноземья 2015 №62 с70-75.

10. Repair of large sinus membrane perforations using stabilized collagen barrier membranes: surgical techniques with histologic and radiographic evidence of success.Testori T, Wallace SS, Del Fabbro M, Taschieri S, Trisi P, Capelli M, Weinstein RL. Int J Periodontics Restorative Dent. 2008 Feb;28(1):9-17.

\title{
Лисицкий Э.С., Тыщенко Н.С. \\ Оценка гигиенического статуса полости рта студентов 5 курса стоматологического факультета курящих табак и потребляющих продукты быстрого приготовления
}

Белгородский государственный наииональный исследовательский университет (Россия, Белгород)

doi:10.18411/spc-18-01-2018-08

idsp: 000001:spc-18-01-2018-08

Актуальность. Современный ритм жизни диктует свои правила. В настоящее время из-за выраженного дефицита времени и высокого уровня психологической нагрузки, среди студентов растёт популярность употребления продуктов быстрого приготовления (ПБП) и курения табака [3]. Россия занимает одно из первых мест в мире по курению табака, при этом, ежегодно количество курящих увеличивается на 1,5-2,0\%. Курение табака приводит к снижению уровня специфического и неспецифического иммунитета, увеличению обсеменённости полости рта, изменению соотношение между аэробами и анаэробами, увеличению риска возникновения заболеваний пародонта[4].

Цель работы: оценка влияния продуктов быстрого приготовления и курения на уровень гигиены полости рта.

Методы и материалы: В нашем исследовании приняло участие 82 студента обучающихся на 5 курсе медицинского института НИУ «БелГУ». Из участников исследования сформировали две группы. В первую вошло 43 курящих студента, во вторую 39 студентов отрицавших факт курения табака. В свою очередь каждая группа делилась на две подгруппы. Согласно условиям исследования участники первых исследуемых подгрупп группы употребляли ПБП дважды в день на протяжении 3 дней, вторых контрольных подгрупп питались в привычном режиме. Условием привлечения к исследованию являлось, изначально удовлетворительное гигиеническое состояние полости рта и информированный отказ от проведения гигиенических мероприятий полости рта на время исследования. Каждой группе проводилось первичнокомплексное обследование полости рта, определялись гигиенические индексы: Федоровой-Володкиной, РМА, Грина-Вермильона, Ph-метрия, осуществлялся сравнительный анализ групп и оценивалась роль влияние факторов ПБП и курения.

\section{Результаты исследования и их обсуждение}

В результате исследования были получены следующие значения индексов гигиены (таблица 1). При анализе данных полученных в ходе исследования можно отметить, что при проведении первичного осмотра обоим группам, в курящей группе исследуемой подгруппы из 22 участников хорошее значение индексов Федоровой-Володкиной имело 15 человек, Грин-Вермильона 16 человек, удовлетворительное значение индексов Федоровой-Володкиной имело 7 человек, Грин-Вермильона 6 человек, среднее значение индексов для всей подгруппы составило РМА 8 \%, Ph-метрия 7,8. 
В контрольной подгруппе, курящей группы из 21 участника хорошее значение индексов Федоровой-Володкиной имело 14 человек, Грин-Вермильона 15 человек, удовлетворительное значение индексов Федоровой-Володкиной имело 7 человек, Грин-Вермильона 6 человек, среднее значение индексов для всей подгруппы составило PMA $9 \%$, Рh-метрия 7,6.

В группе отрицающей факт курения табака в исследуемой подгруппе из 20 участников хорошее значение индексов Федоровой-Володкиной имело 16 человек, Грин-Вермильона 17 человек, удовлетворительное значение индексов

Федоровой-Володкиной имело 4 человека, Грин-Вермильона 3 человека, среднее значение индексов для всей подгруппы составило PMA 4 \%, Ph-метрия 7,3.

В группе отрицающей факт курения табака в контрольной подгруппе из 19 человек хорошее значение индексов Федоровой-Володкиной и Грина-Вермильона имело 15 человек, удовлетворительное значение индексов Федоровой-Володкиной и Грин-Вермильона имело 4 человека, среднее значение индексов для всей подгруппы составило РМА $6 \%$, Рh-метрия 7,2.

После проведения контрольного осмотра полости рта в обеих группах наблюдается снижение уровня гигиены. В курящей группе исследуемой подгруппы отмечается значительный прирост участников с удовлетворительным значением индексов Федоровой-Володкиной с 7 до 19 человек, Грин-Вермильона с 6 до 19 человек, снижение количество участников с хорошим значением индексов гигиены, составило Федоровой-Володкиной с 15 до 3 человек, Грин-Вермильона с 16 до 3 человек, РМА $8 \% \rightarrow 15 \%$, Ph-метрия 7,8 $\rightarrow 7,4$. У контрольной подгруппы, курящей группы прирост лиц с удовлетворительным значениеминдексов Федоровой-Володкиной составил с 7 до 13 человек, Грин-Вермильона с 6 до 11 человек, снижение участников с хорошим значением индексов Федоровой-Володкиной с 14 до 8 человек, Грин-Вермильона с 15 до 10 человек, РМА 9\% $\rightarrow 13 \%$, Ph-метрия $7,6 \rightarrow 7,8$.

У группы отрицающей факт курения табака в исследуемой подгруппе прирост лиц с удовлетворительным значением индексов Федоровой-Володкиной составил с 4 до 9 человек, Грин-Вермильона с 3 до 8 человек, снижение количество участников с хорошим значением индексов гигиены

Федоровой-Володкиной с 16 до 11 человек, Грин-Вермильона с 17 до 12 человек, РМА4\% $\rightarrow 11 \%$, Рh-метрия 7,3 $\rightarrow 6,9$.

У группы отрицающей факт курения табака в контрольной подгруппе прирост лиц с удовлетворительным значением индексов Федоровой-Володкиной составил с 4 до 8 человек, Грин-Вермильона с 4 до 9 человек, снижение количество участников с хорошим значением индексов гигиены Федоровой-Володкиной с 15 до 11 человек ,Грин-Вермильона с 15 до 11 человек,РМА6\% $\rightarrow 9 \%$, Рh-метрия 7,2 $\rightarrow 7,1$.

Таблица1

Гигиенический статус групп

\begin{tabular}{|c|c|c|c|c|c|}
\hline \multirow{3}{*}{ Осмотр } & \multirow{3}{*}{ Индексы } & \multicolumn{2}{|c|}{ Курящие } & \multicolumn{2}{|c|}{ Отрицающие } \\
\hline & & $\begin{array}{l}\text { Исследуемая } \\
\text { подгруппа }\end{array}$ & $\begin{array}{c}\text { Контрольная } \\
\text { подгруппа }\end{array}$ & $\begin{array}{c}\text { Исследуемая } \\
\text { подгруппа }\end{array}$ & $\begin{array}{c}\text { Контрольная } \\
\text { подгруппа }\end{array}$ \\
\hline & & \multicolumn{4}{|c|}{ Среднее значение индексов } \\
\hline \multirow{4}{*}{ Первичный } & $\begin{array}{l}\text { Федоровой- } \\
\text { Володкиной }\end{array}$ & 1,4 & 1,5 & 1,2 & 1,3 \\
\hline & $\begin{array}{c}\text { Грин- } \\
\text { Вермильона }\end{array}$ & 1,0 & 1,1 & 0,4 & 0,6 \\
\hline & PMA & $8 \%$ & $9 \%$ & $4 \%$ & $6 \%$ \\
\hline & Ph тест & 7,8 & 7,6 & 7,3 & 7,2 \\
\hline
\end{tabular}




\begin{tabular}{|c|c|c|c|c|c|}
\hline \multirow{4}{*}{ Повторный } & $\begin{array}{c}\text { Федоровой- } \\
\text { Володкиной }\end{array}$ & 1,9 & 1,7 & 1,6 & 1,5 \\
\cline { 2 - 6 } & $\begin{array}{c}\text { Грин- } \\
\text { Вермильона }\end{array}$ & 1,7 & 1,4 & 0,9 & 0,9 \\
\cline { 2 - 6 } & РМА & $15 \%$ & $13 \%$ & $11 \%$ & $9 \%$ \\
\cline { 2 - 6 } & Рh тест & 7,4 & 7,8 & 6,9 & 7,1 \\
\hline
\end{tabular}

Таким образом в результате проведенного исследования можно сделать вывод, что курение в совокупности с приёмом продуктов быстрого приготовления, значительно ухудшает уровень гигиены полости рта, увеличивает риск возникновения заболеваний парадонта.

$$
* * *
$$

1. Копытов А.А. Динамика показателей десневой жидкости в процессе реабилитации пациентов с автореферат диссертации на соискание ученой степени кандидата медицинских наук / Московский государственный медико-стоматологический университет. Москва, 2007

2. Копытов А.А., Мейрманов А.М., Гальцев О.В. сильфон, расчёт перемещения границы потоков Научные ведомости Белгородского государственного университета. Серия: Медицина. Фармация. 2011. Т. 14. № 10. C. 218-222.

3. Копытов А.А., Московская Н.Б. воздействие продуктов быстрого приготовления на биоценоз зубодесневого кармана, повреждённого пародонтологической терапией Научные ведомости Белгородского государственного университета. Серия: Медицина. Фармация. 2011. Т. 14. № 10. С. 231-235.

4. Копытов А.А., Игишева М.Ю., Дейнека Л.А., Борозенцева В.А. Влияние глин на микрофлору ротовой полости Научные ведомости Белгородского государственного университета. Серия: Естественные науки. 2011. Т. 15. № 9-2 (104). С. 216-218.

\section{Михайлов Ю.Х., Михайлова И.В. \\ Вопросы хирургического лечения хронического тонзиллита}

Чувашский государственный университет имени И.Н.Ульянова (Россия, Чебоксары)

doi:10.18411/spc-18-01-2018-09

idsp: 000001:spc-18-01-2018-09

Проблема хронического тонзиллита (XТ) остается актуальной многие годы, несмотря на постоянно разрабатываемые методы диагностики и лечения. ХТ является одним из наиболее распространенных заболеваний в детском возрасте. Так, по данным ряда авторов, частота этой патологии у детей в возрасте 3 лет составляет 2-3\%, в 5-6 лет - 6-7\%, а к 12 годам достигает 15\%. Среди детей, относящихся к категории часто болеющих, практически каждый второй страдает ХТ. Во взрослой популяции у 10\% населения имеется XT[1].

По статистическим данным количество хронических заболеваний глотки не уменьшается, сохраняясьежегодно практически на одном уровне. Так в 2011 году число заболевших на 100 тысяч детского населения составило 2323,4; в 2012 году 2282,$2 ;$ в $2013-2182,9$ и в 2014 году - 2129,0 [2].

Актуальность ХT связана с тем, что часто наблюдаются инфекционноаллергические осложнения. Некоторые из них, такие как парафарингеальные абсцессы, тонзиллогенный сепсис нередко становятся причиной смерти больного, другие (острая ревматическая лихорадка, хроническая ревматическая болезнь сердца, ревматоидные артриты), гломерулонефриты) снижают качество и продолжительность жизни, нарушают трудоспособность, требуют длительного приема лекарств или необходимости оперативного вмешательства [3].

Ведущим в этиологии патогенезе ХТ и его общих и местных осложнений является $\beta$-гемолитический стрептококк группы А (БГСА), который находят, по разным 